\section{CUTTING CERAMIC} DURABILITY IN MACHINING
PROCESS OF BEARINGS
STEEL 100CR6

ANTON PANDA, JAN DUPLAK, MICHAL HATALA

Technical University of Kosice, Faculty of Manufacturing

Technologies with a seat in Presov, Department of Manufacturing Technologies, , Presov, Slovakia

DOI: 10.17973/MMSJ.2016_10_201633

e-mail: anton.panda@tuke.sk

The theory and practice in engineering industry is not the same. Durability of cutting tools is defined in standard ISO 3685. In standard ISO 3685 is defined T- $\mathrm{V}_{\mathrm{c}}$ dependence for different cutting materials and standard included process evaluation of tool durability for cutting materials made of high speed steel, sintered carbide and cutting ceramic. Standard ISO 3685 contains instructions how to create T- $\mathrm{v}_{\mathrm{c}}$ dependence for cutting tools made of cutting ceramic. In this standard are only instructions how to create $T-v_{c}$ dependence according to Taylor. The article compares $T-v_{c}$ dependencies for various cutting ceramics $\left(\mathrm{Al}_{2} \mathrm{O}_{3}\right.$, $\mathrm{Al}_{2} \mathrm{O}_{3}+\mathrm{ZrO}_{2}, \mathrm{Al}_{2} \mathrm{O}_{3}+\mathrm{TiCN}$ ) with $\mathrm{T}-\mathrm{v}_{\mathrm{c}}$ dependence defined in standard ISO 3685, because this standard describes $T-v_{c}$ dependence for all entered cutting materials together.

KEYWORDS

cutting speed, $\mathrm{T}-\mathrm{v}_{\mathrm{c}}$ dependence, standard ISO 3685 , tool durability, bearing steel $100 \mathrm{Cr} 6$

\section{INTRODUCTION}

Issue cutting tools durability is very topical for small and medium-sized enterprises, because cutting tools durability significantly influences economics of these enterprises.

A lot of manufacturer of cutting tools determined durability of cutting tool only on the assumption or presumption. Problematic of tool durability and its lifetime is defined in standard ISO 3685 . This standard describes how to define $T-v_{c}$ dependence for different cutting materials by means of machining long-term test method. The base of this test is turning workpieces on the equal diameter. [Orlovsky 2010, Cep 2010]

Standard ISO 3685 defines cutting tools durability for workpieces made of steel by means of $T-v_{\mathrm{c}}$ dependence described in this standard according to Taylor. According this standard are dependencies valid for all entered steels together. [10] Turning is the most basic process in machining, because it forms 30\% from all technologies of machining [Isakov 2009, Duplak 2010, Macala 2007]. Turning are used a lot of types cutting tools made from different materials [Helmi 2008, Nagendra 2006]. One of these materials is cutting ceramic. Ceramic cutting tools have been in use for approximately 90 years [Whitney 1994]. As new materials were developed during a specific era, the properties of the cutting tool improved.

However, as new cutting tools were developed, new materials that demanded even more rigorous machining requirements were also developed [Black 2007, Krolczyk 2015, Petru 2014].
Interest in ceramics as a high speed cutting tool material is based primarily on favourable material properties [Neslušan 2007, Vasilko 2009]. As a class of materials, ceramics possess high melting points, excellent hardness and good wear resistance. Unlike most metals, hardness levels in ceramics generally remain high at elevated temperatures which means, that cutting tip integrity is relatively unaffected at high cutting speeds. Ceramics are also chemically inert against most workmetals [Holesovsky 2014, Krolczyk 2015, Michalik 2010].
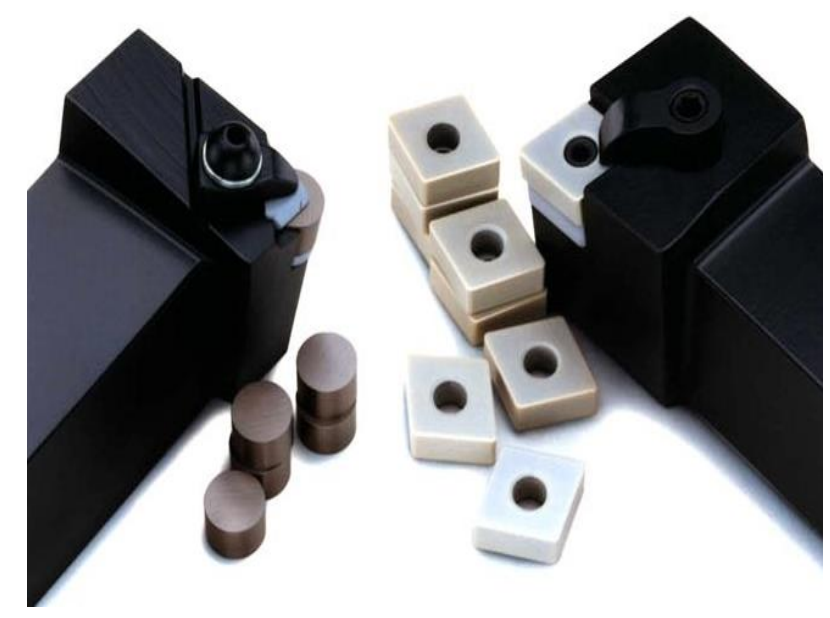

Figure 1. Illustration figure of ceramic cutting tools

\section{SPECIFICATION OF STANDARD ISO 3685}

The standard ISO 3685 describes for all cutting materials common $T-v_{c}$ dependence. Current valid relation of $T-v_{c}$ dependence is described by Taylor formed basics of standard ISO 3685. $T-v_{\mathrm{c}}$ dependence was designed according to Taylor in logarithmic scale [Hloch 2012, Lattner 2014, STN ISO 3685 1999]. Very significant problem in standard ISO 3685 is evaluation of results. Characteristics and dependences for all cutting materials are same [Zelenak 2012, Szarkova 2013].

\section{USED EXPERIMENTAL METHODS}

For determine durability dependence are used two basic methods. First method is short-term durability test and second method is machining long-term test method. For short-term durability test are implementing intermittent cutting test, whose basis is the stub test or strip test. For experiments was used machining long-term test method, because can the whole process describe more precisely. Significant problem with short-term durability test is the generation of suppressors [Cep 2010, Holesovsky 2012].

\section{SPECIFICATION OF MACHINING LONG-TERM TEST METHOD}

Machining long-term test method is essentially only one. Criterion is value of cutting speed and it makes by turning or milling with describes constant cutting parameters, type of cutting tool with defined geometry and graduated cutting speeds to the optimal tip blunting. This test is considered as basic and by this test takes measure objectivity of machinability for others tests. Disadvantage of this test is consumption of workpieces and time consumption [Cuma 2009, STN ISO 3685 1999].

Description of machining long-term test method:

1) Time measurement process of depreciation on back of tool VBB, for few value of cutting speeds at 
constant cutting parameters and construction curve of blunting.

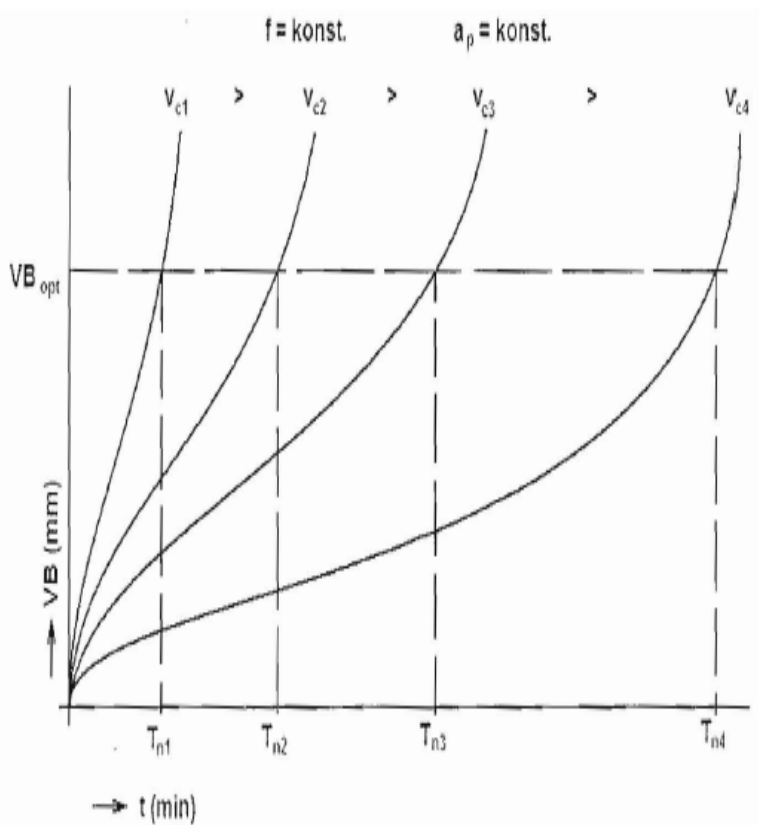

Figure 2. Curve of blunting for variable cutting speeds [Cuma 2009]

2) Specification criterion of depreciation $V B_{\text {opt }}$ and determination tip durability for each cutting speed.

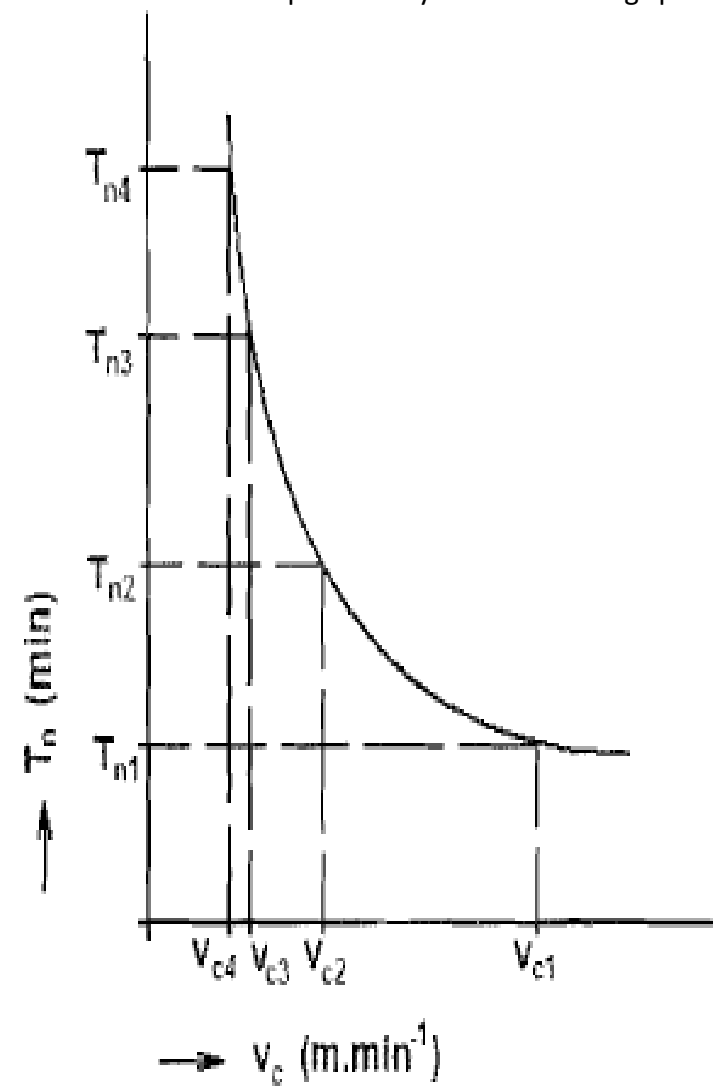

Figure 3. Determination of particular durability by the criterion of depreciation [Cuma 2009]

3) Construction $T_{n}=f\left(v_{c}\right)$ dependence in logarithmic scale and determination index of machinability for selected durability under comparison cutting speed tested material and etalon material.

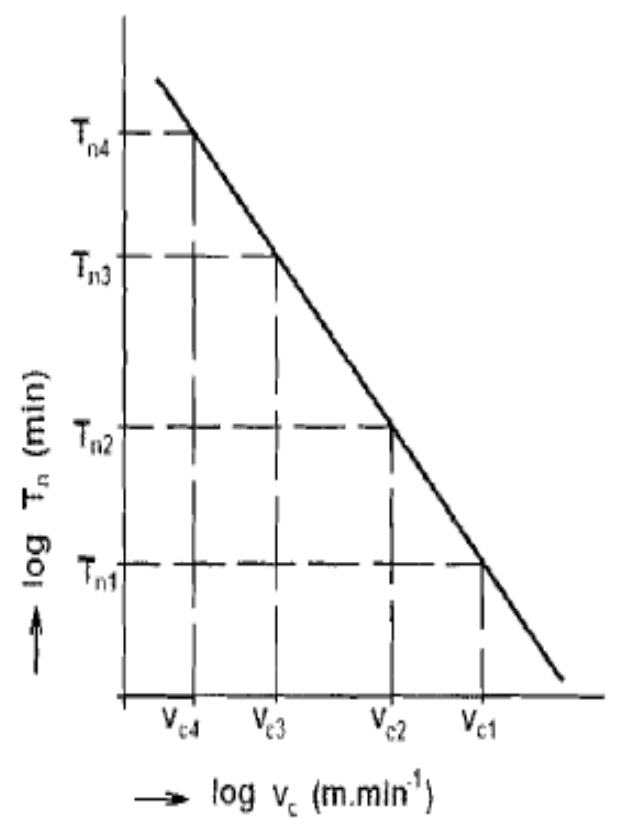

Figure 4. $T-\mathrm{v}_{\mathrm{c}}$ dependence in logarithmic scale [Cuma 2009]

\section{EXPERIMENT SPECIFICATION}

Very important step, before the actual experiments is specification of technological system. In technological system for these experiments were contained machine - tools - workpiece.

\subsection{Used machine}

The first step was to select appropriate machine. For tests was selected universal center lathe SU 50, due to stiffness this device and its uses for experiments in standard ISO 3685.

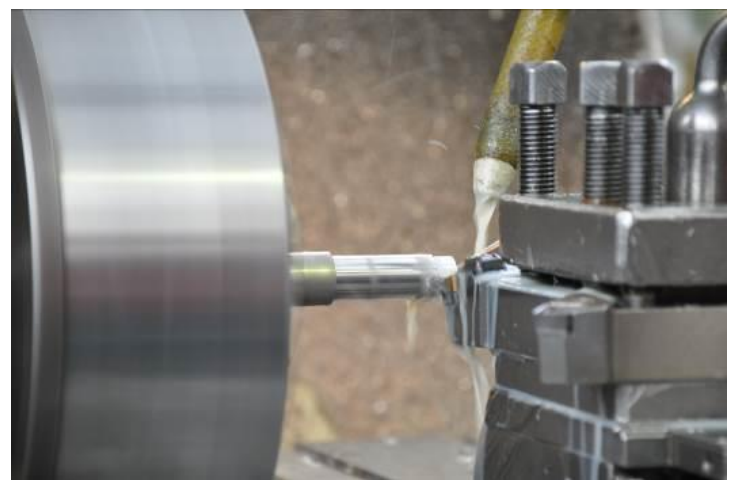

Figure 5. Machining process on lathe SU 50

\subsection{Used cutting tools}

In second step were specified tools for experiments. Cutting tools for experiments were selected according to problem assignment that was defined in introduction. For experiments were selected three types of cutting ceramics tools. Cutting plates selected for experiments are: $\mathrm{Al}_{2} \mathrm{O}_{3}, \mathrm{Al}_{2} \mathrm{O}_{3}+\mathrm{ZrO}_{2}$, $\mathrm{Al}_{2} \mathrm{O}_{3}+\mathrm{TiCN} . \mathrm{Al}_{2} \mathrm{O}_{3}$ are defined as basic cutting ceramics type and it is pure oxide ceramics, more precisely alumina without coatings and additives. $\mathrm{Al}_{2} \mathrm{O}_{3}+\mathrm{ZrO}_{2}$ are defined as white ceramics with high tenacity and wear resistance. Using of this ceramic type is for turning by high cutting speeds. $\mathrm{Al}_{2} \mathrm{O}_{3}+\mathrm{TiCN}$ are defined as black ceramics and there are recommended for roughing and finishing operations. 


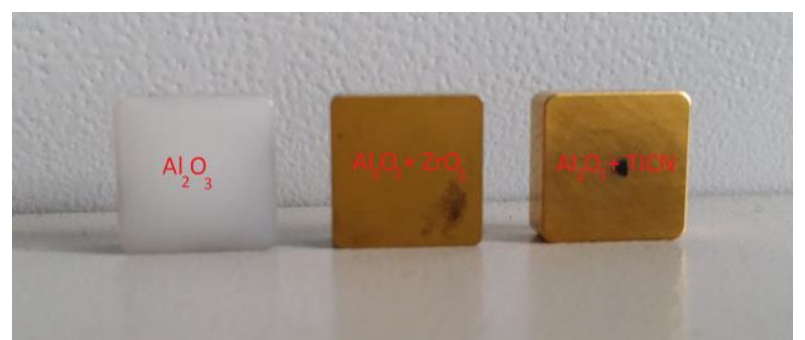

Figure 6. Machining process on lathe SU 50

\subsection{Specification of workpiece material}

In the third step were specified the workpieces for experiments. Workpieces for experiments are made of steel $100 \mathrm{Cr}_{6}$. Material for workpieces is from specific material list with guaranteed chemical structure and mechanical properties.

Table 1. Chemical structure of material $100 \mathrm{Cr}_{6}$

\begin{tabular}{|c|c|c|c|c|}
\hline \multicolumn{5}{|c|}{ Chemical structure of $100 \mathbf{C r}_{6}[\%]$} \\
\hline $\mathbf{C}$ & $\mathbf{M n}$ & $\mathbf{S i}$ & $\mathbf{C r}$ & $\mathbf{F e}$ \\
\hline 0.9 & 0.37 & 0.27 & 1.45 & 96.7 \\
\hline $\mathbf{N i}$ & $\mathbf{C u}$ & $\mathbf{P}$ & $\mathbf{S}$ & \\
\hline 0.1 & 0.19 & 0.001 & 0.003 & \\
\hline
\end{tabular}

Table 2. Mechanical properties of material $100 \mathrm{Cr}_{6}$

\begin{tabular}{|c|c|c|c|}
\hline \multicolumn{4}{|c|}{ Mechanical properties of 100Cr6 } \\
\hline $\begin{array}{c}\text { Rm } \\
{[\mathbf{M P a}]}\end{array}$ & $\mathbf{A 5}[\%]$ & HB & $\mathbf{R p}_{\mathbf{0}, 2}[\mathbf{M p a}]$ \\
\hline 700 & 27 & 195 & 410 \\
\hline
\end{tabular}

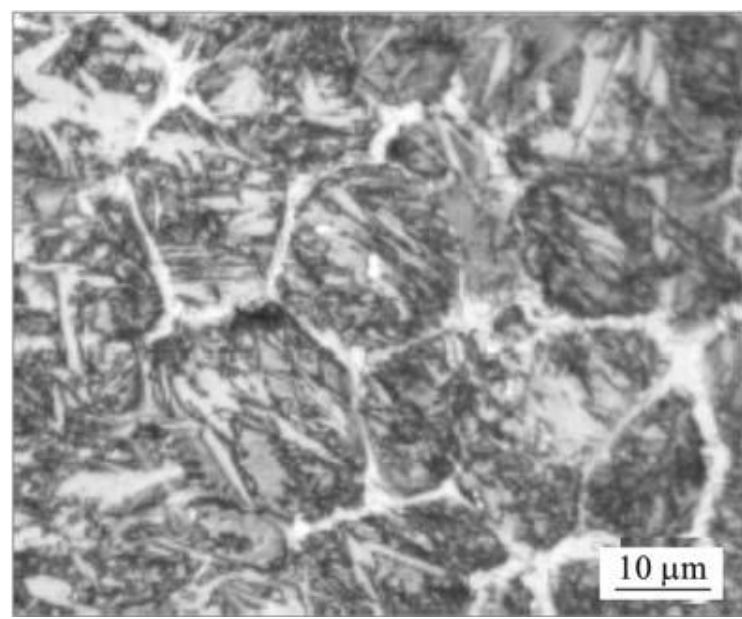

Figure 7. Microstructure of $100 \mathrm{Cr}_{6}$

These experiments were made under defined technological conditions. Tool durability was proven with kinetic machining long-term test method. Experiment inputs were workpieces with equal diameters; those were used at turning process. For each cutting speed the diameter should have the same value, because examined material has different consistency in different depth. Experiment was finished once wear criterion was reached.

\section{TECHNOLOGICAL CONDITIONS USED FOR EXPERIMENTS}

$$
v_{\mathrm{c}}=20-700 \mathrm{~m} \cdot \mathrm{min}^{-1} ; a_{\mathrm{p}}=0.2 \mathrm{~mm} ;
$$

$f=0.1 \mathrm{~mm} ; r_{\varepsilon}=0.8 \mathrm{~mm} ; \kappa_{\mathrm{r}}=80^{\circ} ; \kappa_{\mathrm{r}}^{\prime}=10^{\circ} ; V B=0.3 \mathrm{~mm}$;
Table 3. Results of $T-v_{c}$ dependence for $\mathrm{Al}_{2} \mathrm{O}_{3}$

\begin{tabular}{|c|c|c|c|}
\hline $\begin{array}{c}\boldsymbol{V}_{\mathrm{c}} \\
{\left[\mathrm{m} \cdot \mathrm{min}^{-1}\right]}\end{array}$ & $\begin{array}{c}T \\
{[\mathrm{~min}]}\end{array}$ & $\begin{array}{c}\boldsymbol{V}_{\mathrm{c}} \\
{\left[\mathrm{m}_{\mathrm{min}}{ }^{-1}\right]}\end{array}$ & $\begin{array}{c}T \\
{[\mathrm{~min}]}\end{array}$ \\
\hline 20 & 17 & 180 & 15 \\
\hline 30 & 15.5 & 220 & 10 \\
\hline 47 & 27 & 234 & 9 \\
\hline 51 & 27.1 & 250 & 9 \\
\hline 56 & 27.2 & 270 & 9 \\
\hline 78 & 28.5 & 369 & 7.5 \\
\hline 100 & 30 & 430 & 6.4 \\
\hline 123 & 29 & 504 & 6 \\
\hline 128 & 28.7 & 550 & 5.3 \\
\hline 136 & 28 & 580 & 5.1 \\
\hline 140 & 25 & 640 & 4.7 \\
\hline 150 & 20.5 & 690 & 4.3 \\
\hline 155 & 20 & 700 & 4.1 \\
\hline & & & \\
\hline
\end{tabular}

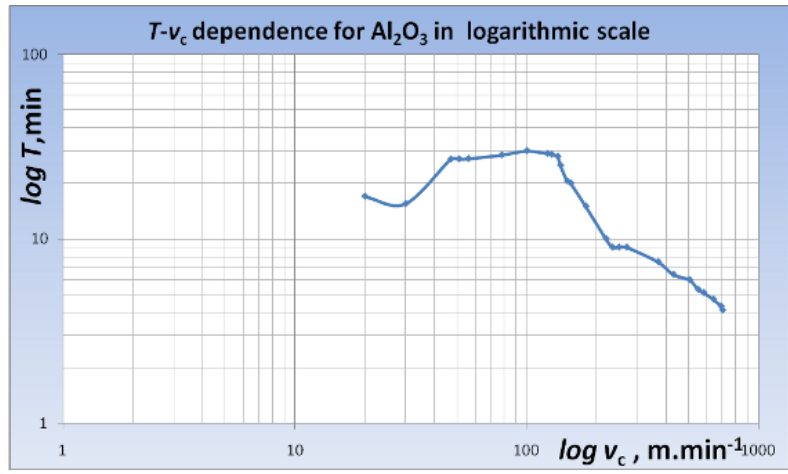

Figure 8. $\mathrm{T}-\mathrm{V}_{\mathrm{c}}$ dependence for $\mathrm{Al}_{2} \mathrm{O}_{3}$ in logarithmic scale

Table 4. Results of $T-v_{\mathrm{c}}$ dependence for $\mathrm{Al}_{2} \mathrm{O}_{3}+\mathrm{ZrO}_{2}$

\begin{tabular}{|c|c|c|c|}
\hline $\begin{array}{c}v_{c} \\
{\left[m \cdot \min ^{-1}\right]}\end{array}$ & $\begin{array}{c}T \\
{[\mathrm{~min}]}\end{array}$ & $\begin{array}{c}v_{\mathrm{c}} \\
{\left[\mathrm{m} \cdot \mathrm{min}^{-1}\right]}\end{array}$ & $\begin{array}{c}T \\
{[\mathrm{~min}]}\end{array}$ \\
\hline 20 & 19 & 180 & 38.7 \\
\hline 30 & 18 & 220 & 34.6 \\
\hline 47 & 32 & 234 & 34.2 \\
\hline 51 & 33 & 250 & 33.7 \\
\hline 56 & 35 & 270 & 31.2 \\
\hline 78 & 40.1 & 369 & 24.4 \\
\hline 100 & 46.3 & 430 & 22.6 \\
\hline 123 & 44.7 & 504 & 19 \\
\hline 128 & 44.6 & 550 & 17.1 \\
\hline 136 & 44.4 & 580 & 16.3 \\
\hline 140 & 44.3 & 640 & 11.7 \\
\hline 150 & 44.1 & 690 & 9.6 \\
\hline 155 & 43.9 & 700 & 9.1 \\
\hline
\end{tabular}

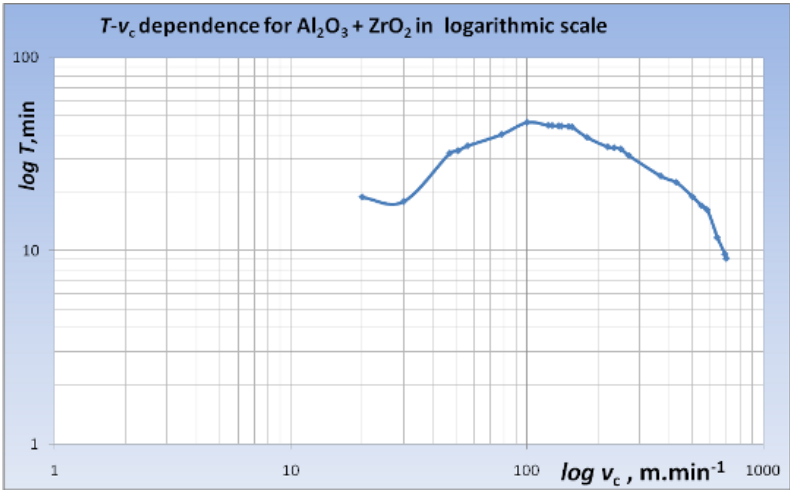

Figure 9. $\mathrm{T}-\mathrm{v}_{\mathrm{c}}$ dependence for $\mathrm{Al}_{2} \mathrm{O}_{3}+\mathrm{ZrO}_{2}$ in logarithmic 
Table 5. Results of $\mathrm{T}-\mathrm{v}_{\mathrm{c}}$ dependence for $\mathrm{Al}_{2} \mathrm{O}_{3}$

\begin{tabular}{|c|c|c|c|}
\hline $\begin{array}{c}\boldsymbol{v}_{\mathrm{c}} \\
{\left[\mathrm{m} \cdot \mathrm{min}^{-1}\right]}\end{array}$ & $\begin{array}{c}T \\
{[\mathrm{~min}]}\end{array}$ & $\begin{array}{c}\boldsymbol{V}_{\mathrm{c}} \\
{\left[\mathrm{m}_{\mathrm{min}}{ }^{-1}\right]}\end{array}$ & $\begin{array}{c}T \\
{[\mathrm{~min}]}\end{array}$ \\
\hline 20 & 19.7 & 180 & 41.1 \\
\hline 30 & 19 & 220 & 39.2 \\
\hline 47 & 34 & 234 & 37.9 \\
\hline 51 & 35 & 250 & 36.2 \\
\hline 56 & 35.9 & 270 & 34.8 \\
\hline 78 & 41.7 & 369 & 26.9 \\
\hline 100 & 49.9 & 430 & 23.1 \\
\hline 123 & 48.1 & 504 & 20.7 \\
\hline 128 & 47.8 & 550 & 18.3 \\
\hline 136 & 47.2 & 580 & 16.9 \\
\hline 140 & 46.9 & 640 & 13.8 \\
\hline 150 & 45.2 & 690 & 11.4 \\
\hline 155 & 45 & 700 & 10.2 \\
\hline & & & \\
\hline
\end{tabular}

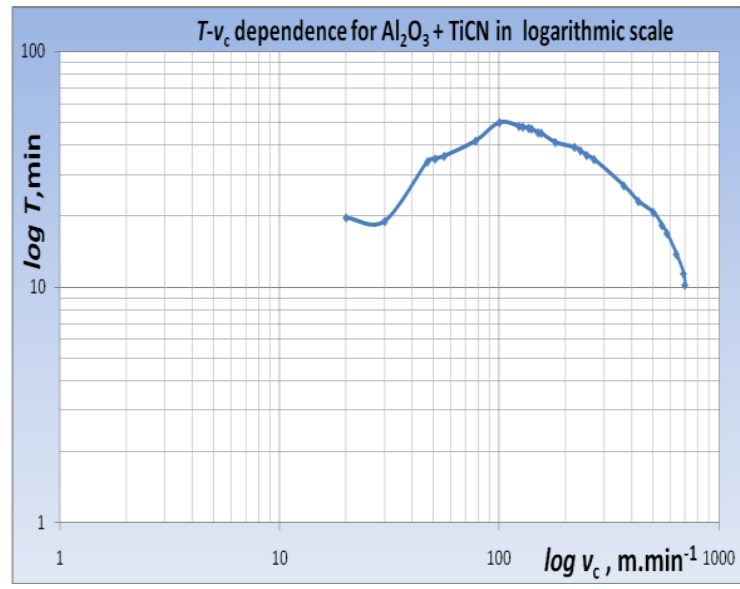

Figure 10. $\mathrm{T}-\mathrm{v}_{\mathrm{c}}$ dependence for $\mathrm{Al}_{2} \mathrm{O}_{3}+\mathrm{TiCN}$ in logarithmic scale

\section{CONCLUSION}

Every one process in engineering industry is defined by some standard ISO. Procedures for technical sciences are defined in standards these standards described technological conditions, dependencies, settings, diverse cutting parameters etc. Precision and completeness of standard ISO represents primary factor in technical sciences. Defects and imprecision described in standard ISO need to be fixed. Experiments are necessary to prevent false information. This paper was oriented on durability selected ceramic cutting plates in machining process of steel $100 \mathrm{Cr}_{6}$.

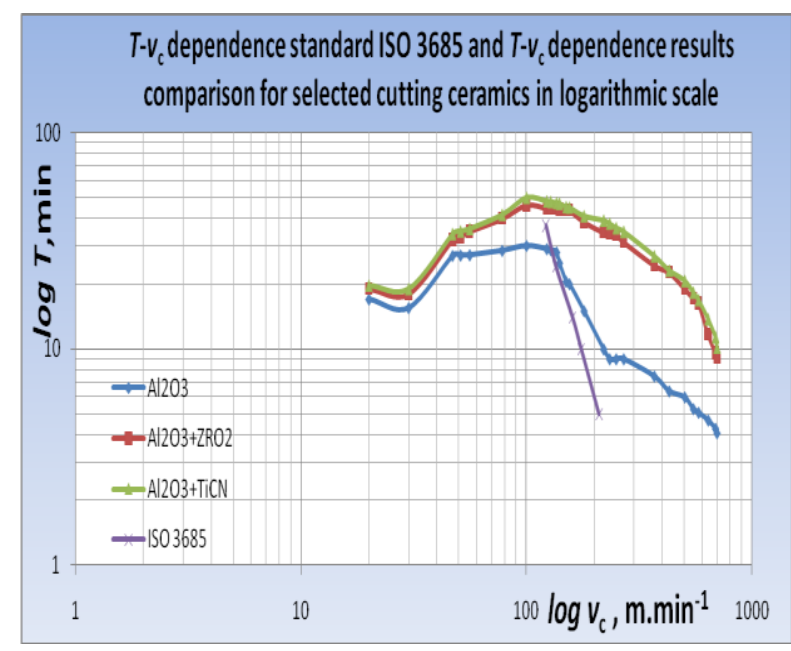

Figure 11. Comparison standard ISO 3685 and experiment results
The durability issue of cutting tools is defined in standard ISO 3685. This standard defines all process how to create and to define cutting tools durability by means of $T-v_{c}$ dependence according to Taylor. Executed experiments showed, that between the standard ISO 3685 and experiment results are expressive differences. The following figure (11) shows differences between standard ISO 3685 and selected ceramic plates. Experiment was executed for three types ceramic cutting plates and for all three types are in graph visible differences. Standard ISO 3685 is invalid for machining of steel $100 \mathrm{Cr}_{6}$ by ceramic cutting plates.

For small and medium-sized enterprises is durability of cutting tool very important factor how to save some money. For these enterprises means prolong the life of cutting tool the obtaining of important gains, that enabling them to develop. Execution experiments defined the optimized cutting tools durability under defined technological conditions in machining process of steel $100 \mathrm{Cr}_{6}$. Under defined technological conditions were the highest durability ceramic cutting plates at the cutting speed of about $100 \mathrm{~m} \cdot \mathrm{min}^{-1}$. The highest durability was under defined technological conditions for cutting plates made of $\mathrm{Al}_{2} \mathrm{O}_{3}+\mathrm{TiCN}$

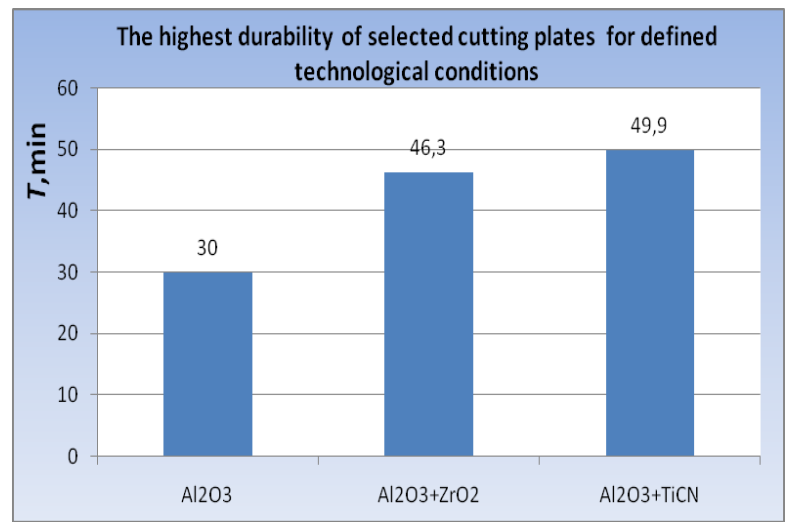

Figure 12. The highest durability of selected cutting plates

Deeper exploration of durability cutting materials defined in standard ISO 3685 is very important, because only valid information and correct dependencies may be included in technical standards.

\section{ACKNOWLEDGMENTS}

This work has been supported by research grant VEGA $1 / 0409 / 13$.

\section{REFERENCES}

[Allo 2013] Allo, S., Krocko, V., Korenko, M., Andrassyova, Z., Foldesiova, D. "Effect of chemical degreasing on corrosion stability of components in automobile industry". In Advanced Materials Research. ISSN 1022-6680, 2013, vol. 801, special iss, p. 19-23.

[Black 2007] Black, J. T. and Kohser, R. A. DeGarmo's Materials \& Processes in Manufacturing. USA: Wiley India Private, Limited. ISBN 812654046X

[Brezinova 2014] Brezinova, J., Guzanova, A., Spisak, E. Assessment of properties thermal sprayed coatings realised using cermet blend powder. In: Metalurgija, 2014, vol. 53, No. 4, pp. 661-664, ISSN 0543-5846.

[Cep 2010] Cep, R. et al. Ceramic cutting tool tests with interupted cut simulator. IN-TECH 2010, 2010, Proceedings of International Conference on Inovative Technologies, pp 144148, ISBN 978-80-904502-2-6 
[Cep 2014] Cep, R., Janasek, A., Petru, J., Sadilek, M., Mohyla, P., Valicek, J., Harnicarova, M., Czan, A. "Surface roughness after machining and influence of feed rate on process", 2014. In: Key Engineering Materials. Vol. 581 (2014), p. 341-347., ISSN 1013-9826

[Cuma 2009] Cuma, M. et al. The impact of cutting fluids on machining. Slovakia: TUKE FVT PO. ISBN 978-80-553-0243-0 [Duplak 2010] Duplak, Identification of comprehensive $T-v_{c}$ dependence. Diploma Thesis. Prešov: TUKE FVT PO, 2010 [Duranik 2013] Duranik, T., Ruzbarsky, J., Manlig F. Proposal for possibilities of increating production productivity of thermosets compression mplding with using process simulation software. In: Applied Mechanics and Materials, Trans Tech Publications, Zurich, Switzerland, vol. 308, 2013, p. 192-194.

[Fabian 2013] Fabian, S., Salokyova, S. The technological head vibrations with different abrasive mass flow rates. In: Applied Mechanics and Materials, TTP, Zurich, Switzerland, vol.308, 2013, p.1-6.

[Gombar 2013] Gombar, M., Vagaska, A., Kmec, J., Michal, P. Microhardness of the Coatings Created by Anodic Oxidation of Aluminium. In: Applied Mechanics and Materials, Trans Tech Publications, Zurich, Switzerland, vol. 308, 2013, p. 95-100.

[Helmi 2008] Helmi, A. Y. and El-Hofy, H. Machining Technology - Machine Tools and Operations. USA: CRC Press, 2008. ISBN 978-1-4200-4339-6

[Hloch 2012] Hloch, S. et al. Classification of technical materials according to classes machinability for hydroabrasive cutting. Metalurgija, January 2012, Vol. 51, No. 1, pp 125-128

[Holesovsky 2012] Holesovsky, F. et al. GICS for Grinding Process Optimization. Manufacturing Technology, 2014, Vol. 12, No. 12, pp 22-26, ISSN 1213-2489

[Holesovsky 2014] Holesovsky, F. et al. Effect of machining the load capacity notched components. Key Engineering Materials, 2014

[Isakov 2009] Isakov, E. Cutting Data for turning of steel. USA: Industrial Press, Inc., 2009. ISBN 978 - 0 - 8311- 3314-6 [Janekova 2014] Janekova, J., Kovac, J., D. Onofrejova, D. Modelling of Production Lines for Mass Production of Sanitary Products. Elsevier, Netherlands, 2014. In: Procedia Engineering, Elsevier, Vol. 2014, no. 96(2014), p. 330-337, 2013

[Jurko 2016] Jurko, J., Panda, A., Valicek, J., Harnicarova, M. Pandova, I. Study on cone roller bearing surface roughness improvement and the effect of surface roughness on tapered roller bearing service life. In: The International Journal of Advanced Manufacturing Technology. Springer London Ltd, pp. 1099-1106, Volume 82, Issue 5-8, 2016, ISSN 0268-3768

[Krehel 2013] Krehel, R., Straka, L., Krenicky, T. Diagnostics of Production Systems Operation Based on Thermal Processes Evaluation. In: Applied Mechanics and Materials, Trans Tech Publications, Zurich, Switzerland, vol. 308, 2013, p. 121-126.

[Krolczyk 2015] Krolczyk, G. et al. Investigation of selected surface integrity features of duplex stainless steel (DSS) after turning. Metalurgija, January 2015, Vol. 54, No. 1, pp 91-94. ISSN 0543-5846

[Lattner 2014] Lattner, M. and Holesovsky, F. Effect of machining the load capacity notched components. Manufacturing Technology, 2014, Vol. 14, pp. 47-50

[Lesso 2010] I. Lesso, I., Flegner, P., Sujansky, M., Spak E. Research of the possibility of application of vector quantisation method for effective process control of rocks sisintegration by rotary drilling. In: Metalurgija. Vol. 49, no. 1, p. 61-65. (CMS). ISSN 0543-5846, (2010)

[Macala 2007] Macala, J. and Pandova, I. Natural zeoliteclinoptilolite - raw material serviceable in the reduction of toxical components at combustion engines noxious gases.
Gospodarka surowcami mineralnymi, 2007, Vol. 23, No. 4, pp 19-25. ISSN 0860-0953

[Michalik 2010] Michalik, P. and Zajac, J. Intelligently programming of holes machining. Manufacturing Engineering, 2010, Vol. IX, No. 4, pp 63-65, ISSN 1335-7972

[Monkova 2013] Monkova, K., Monka, P., Jakubeczyova, D. The research of the high speed steels produced by powder and casting metallurgy from the view of tool cutting life. In:Applied Mechanics and Materials, TTP, Switzerland, vol. 302, no. 302, 2013, p. 269-274.

[Mrkvica 2012] Mrkvica, I., Janos, M., Sysel, P. Cutting efficiency by drilling with tools from different materials. Advanced Materials Research, Materials Processing Technology II. 2012, Vols. 538-541, pp. 1327-1331.

[Nagendra 2006] Nagendra, B. S. P. and Mittal, R. K. Elements of Manufacturing Proces. India: PHI Learning Pvt. Ltd., 2006. ISBN 978-81-203-1958-5

[Neslusan 2007] Neslusan, M. et al. Experimental methods in splinter machining. Slovakia: EDIS ZU Zilina. ISBN 978-80-8070711-8

[Orlovsky 2010] Orlovsky, I. et al. Creation of simulation model of ceramic granulate production in spraying kiln. Technical Gazette, 2010, Vol. 17, No. 4, pp 419-423. ISSN 1330-3651

[Panda 2011a] Panda, A., Jurko, J., Dzupon, M., Pandova, I.: „Optimalization of heat treatment bearings rings with goal to eliminate deformation of material“. In: Chemicke listy, 2011, vol. 105, issue 16, ISSN 0009-2770, p. 459-461.

[Panda 2011b] Panda, A., Duplak, J., Jurko, J. „Analytical Expression of $\mathrm{T}-\mathrm{v}_{\mathrm{c}}$ dependence in standard ISO 3685 for cutting ceramic". In: Key Engineering Materials, Trans Tech Publications, Zurich, Switzerland, 2011, vol. 480-481, ISSN 1013-9826, p. 317-322.

[Panda 2013] Panda, A., Duplak, J., Jurko, J. „Theory and Practice in the process of $T-\mathrm{v}_{\mathrm{c}}$ dependence creation for selected cutting material“. In: Advanced Materials Research, Trans Tech Publications, Zurich, Switzerland, 2013, vol. 716, ISSN 10226680, p. 261-265.

[Panda 2016] Panda, A., Jurko, J., Pandova, I. Monitoring and Evaluation of Production Processes. An Analysis of the Automotive Industry. Monograph, Springer International Publishing, Switzerland, 2016, (8.4.2016), 117 pages, ISBN 9783-319-29441-4

[Pandova 2012] Pandova, I., Gondova, T., Dubayova, K. Natural and modified clinoptilolite testing for reduction of harmful substance in manufacturing exploitation. In: Advanced Materials Research, vol.518-523, Switzerland, 1757-1760 p. 2012, ISSN 1022-6680.

[Pandova 2014] Pandova I. Nitrogen oxides reduction by zeolite sorbents in manufacturing use. In: Advanced Materials Research, Trans Tech Publications, Zurich, Switzerland, 2014, vol. 937 (2014), ISSN 1022-6680, p. 487-490.

[Peterka 2014] Peterka, J., Pokorny, P. Influence of the Lead Angle from the Vertical Axis Milling on Effective Radiu sof the Cutter. In: Key Engineering Materials, Trans Tech Publications Inc. Switzerland, vol. 581 (2014), No. 581, p. 44-49. ISSN 10139826.

[Petru 2014] Petru, J. et al. The Effect of Thermal Shocks on Wear of Exchangeable Sintered Carbide Inserts during the Cutting Process. Manufacturing Technology, 2014, Vol. 14, No. 4, pp 590-596, ISSN 1213-2489

[Prislupcak 2016] Prislupcak, M., Panda, A. Comparsion and Analysis of the Flow Rate. In: Key Engineering Materials, Trans Tech Publications, Zurich, Switzerland, 2016, vols. 663-696 (2016), pp. 197-204, ISSN 1013-9826.

[Ragan 2012] Ragan, E., Dobransky, J., Baron, P., Kocisko, M., Svetlik, J. Dynamic of taking out molding parts at injection 
molding. Metallurgy No.4/2012,vol.51, Zagreb, Croatia, Croatian Metallurgical Society, 567-570 p.

[Rimar 2014] Rimar, M., Fedak, M., Mihalcova, J., Kuna, S. Adaptive rejection filter for the drives stabilization of pressure die-casting machines. In: Advances in Mechanical Engineering. 2014), p. 1-10, ISSN 1687-8132.

[STN ISO 3685 1999] Tool-life testing with single-point turning tools, 1999

[Szarkova 2013] Szarkova, V. et al. Influence of longitudinal cold rolling on the surface topography of low carbon structural steel. Tehnicki Vjestnik, 201, Vol. 20, No. 4, pp 705-709. ISSN 1330-3651

[Vasilko 2009] Vasilko, K. Theory and practise of splinter machining. Slovakia: TUKE FVT PO. ISBN 978-80-553-0152-5

[Whitney 1994] Whitney, E. D. Ceramic Cutting Tools. USA: William Andrew Publishing, 1994. ISBN 978-0-8155-1355-0

[Zelenak 2012] Zelenak, M. et al. Comparison of mechanical properties of surface layers with use of nanoindentation and microindentation tests. Metalurgija, 2012, Vol. 51, pp 309-312, ISSN 0543-5846

[Zaborowski 2007] T. Zaborowski, Ekowytwarzanie. Gorzow, p.100 (2007)

\section{CONTACTS:}

Prof., M. S. E (Ing.) Anton Panda, PhD.

M. S. E. (Ing.) Jan Duplak, PhD.

Assoc. prof., M. S. E. (Ing.) Michal Hatala, PhD.

Technical University of Kosice with a seat in Presov

Faculty of Manufacturing Technologies

Bayerova 1, Presov, 080 01, Slovakia

e-mail: anton.panda@tuke.sk

e-mail: jan.duplak@tuke.sk

e-mail: michal.hatala@tuke.sk 